\title{
近世城下町岩国の錦見地区における 城下町設計の論理
}

\author{
阿部 貴弘 1 ・松下 直道 2 \\ 1 正会員 日本大学教授 理工学部まちづくり工学科（†101-8308 東京都千代田区神田駿河台 1-8-14） \\ E-mail: abe.takahiro@nihon-u.ac.jp \\ 2非会員 東京都 都市整備局（干163-8001 新宿区西新宿 2-8-1） \\ E-mail: Naomichi_Matsushita@member.metro.tokyo.jp
}

\begin{abstract}
本研究は，近世城下町岩国の錦見地区を対象に，その設計論理を解明することを目的とする. 分析の結 果, 錦見地区の街路網は, 街区形態の基準を踏まえつつ, 雨水の排水勾配を確保するため微地形に配慮し て配置されたこと, 一方宅地は, 背割線を介して隣接する武家屋敷等の奥行に配慮しながら, 街路の両側 でほぼ等しい奥行となるよう割り付けられたこと等を明らかにした。

さらに, これらの分析を通して, 筆者らが既往研究で提示した城下町町人地の設計論理を読み解くため の方法論の精緻化を図り，大坂及び江戸のように大縮尺の近代測量図が遺されていない城下町においても， 近世の絵図の分析や近代の微地形図に基づく地形分析を行うことにより, 既往研究の方法論が適用可能で あることを明らかにした。
\end{abstract}

Key Words : design principle, castle town, urban fabric, infrastructure, Iwakuni

\section{1. はじめに}

我が国の主要都市の多くは，近世城下町を基盤として 発展してきた。しかし，そうした城下町がどのような論 理に基づき設計されたのか，いまだ十分に解き明かされ ているとは言い難い. その要因の一つに, 城下町の設計 論理について記述した史料がきわめて少ないという文献 史料の限界があった 1),2)、そこで筆者らは，一連の既往 研究3),4),5,0,7)において，文献史料のみに頼らない，近代測 量図の地図計測による定量的分析という新たな方法論を 提示し，この方法論に基づき，近世城下町大坂及び江戸 の町人地における設計論理を解明してきた.

ところがこの方法論は，明治初期に作成された縮尺 5,000 分の 1 程度の大縮尺の近代測量図を主な分析史料と して用いることから，たとえばそうした大縮尺の近代測 量図が作成されていない城下町においては，何らかの方 法で分析史料の欠如を補う必要があるなど，大坂及び江 戸以外の城下町への適用に向けた方法論の精緻化が必要 であった.

一方，近世城下町岩国を基盤とする山口県岩国市では， 現在，城下町中心部に架かる錦帯橋の世界遺産登録をめ ざし, 錦帯橋の顕著な普遍的価值 (OUV (outstanding universal value））に関する議論が進められている。 その過
程において，錦帯橋の架橋位置の合理性を確認するため， 城下町町人地の設計論理の解明が不可欠となっている. しかし，近世城下町岩国については，竹林 ${ }^{8}$ 及び上杉 9) により，城下町の構成や各町の成立過程については概説 されているものの，町人地の設計論理については明らか にされておらず，その解明が強く要請されている.

周防国と安芸国との国境に位置する城下町岩国は, 1601（慶長 6）年に岩国入りした吉川広家によって開か れた近世城下町で，横山，錦見，川西，今津の 4 地区か らなる（図-1）。錦川右岸の横山地区は，山上に城郭が 置かれ，その麓に上級武士の屋敷が配置された．横山地 区と錦帯橋で結ばれる錦川左岸の錦見地区は，城下町岩 国の中心となる地区であり，さらにその中心の地区西部 には錦見七町（玖珂町，柳井町，米屋町，塩町，材木町， 魚町, 豆腐町）と呼ばれる町人地が置かれ，この町人地 を囲むように中下級武士の屋敷が配置された。一方，横 山地区の南に位置する錦川右岸の川西地区は，山陽道の 脇道沿いを中心に下級武士の屋敷や上級武士の下屋敷な どが配置された．また，錦川河口部に位置する今津地区 は，水軍の拠点が置かれたほか，その生活を支えるため の町屋などが配置された ${ }^{10)}$.

こうした城下町岩国の立地は，以下に示す理由から， 近世城下町のなかでも稀な例であるとされる ${ }^{11)}$. 


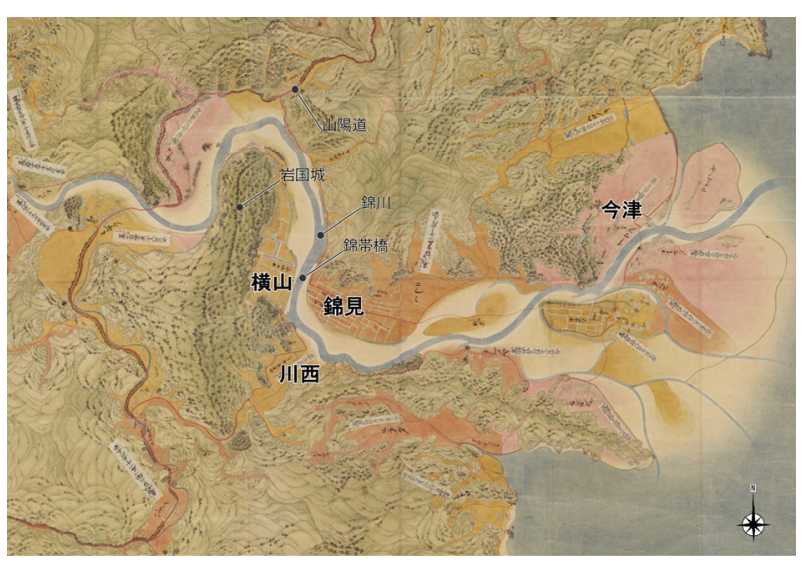

図-1 近世城下町岩国の位置図（『御領内之図（岩国領全 図）』（1668（寛文 8）年）（部分）に加筆）

まず，我が国において，1600（慶長 5）年の関原の 戦い以降に新造された城郭は，平野部の平城もしくは平 山城が主流であったが，1608（慶長 13）年に䇋工した岩 国城は，山上の山城として築造された。また，図-1に示 す通り，武家地や町人地が置かれた麓（城下）の平地部 は，城下町を開くにはそもそも面積が不十分であったた め, 城下の 4 地区が分散して配置せざるを得ない構造と なった. さらに, 近世城下町は主に陸上交通と水上交通 の要衝に開かれたが，岩国の場合，近傍に山陽道が通る ものの，それが直接城下までは引込まれてまれておらず, また，錦帯橋の架かる錦川が城下の中央部に流れている ものの，その錦川から町人地が置かれた錦見地区に舟運 路が引込まれていないなど，交通の要衝としての機能が 十分に生かされているとは言い難い立地であった.

各城下町における近世の人口や面積に関して, 現在の ような統一的かつ精確な統計データは整えられていない ことから精緻な比較はできないが，こうした岩国の立地 特性をより明確に把握するため, 中心町人地の面積につ いて，他の近世城下町とのおおよその比較を試みる.

まず，岩国の中心町人地である錦見七町は，概小 $0.12 \mathrm{~km} \times 0.45 \mathrm{~km}=0.054 \mathrm{~km}^{2}$ の面積をもつ. これに対して， 大坂の中心町人地である上町, 船場, 島之内, 下船場地 区の面積は，あわせて概小 $3.00 \mathrm{~km} \times 2.70 \mathrm{~km}=8.10 \mathrm{~km}^{2}$ ，江 戸の中心町人地である日本橋, 京橋, 銀座地区の面積は, あわせて概ね $3.50 \mathrm{~km} \times 2.00 \mathrm{~km}=7.00 \mathrm{~km}^{2}$ となり，当時の二 大城下町と比べて, 岩国はかなり小規模な城下町であっ たことがわかる，一方，石高及び領内人口が同程度の城 下町大洲 ${ }^{12)}$ と比較してみても，大洲の中心町人地の面積 は岩国の約 2 倍, 概小 $0.50 \mathrm{~km} \times 0.20 \mathrm{~km}=0.100 \mathrm{~km}^{2}$ であり， 岩国がいかに小規模であったかを知ることができる.

大坂や江戸をはじめとする平城もしくは平山城の近世 城下町に比へ，山城という特徵的な立地の城下町岩国の 町人地がいかなる論理に基づき設計されたのか，その解 明はきわめて興味深い.さらに，大坂及び江戸において
適用した近世城下町町人地の設計論理を解明するための 万法論が，岩国のような特徵的な立地の城下町において も適用可能であるかを検証することは，方法論の精緻化 にあたり有効であると考える.

こうした背景を踏まえ，本研究は，近世城下町岩国の 中心である錦見地区を対象に，既往研究において筆者ら が提示した方法論に基づき，その設計論理を解明すると ともに，錦見地区の分析を通して，既往研究の方法論の 精緻化を図ることを目的とする.

\section{2. 研究方法}

\section{(1) 既往研究における方法論}

筆者らはこれまで，一連の既往研究において，城下町 町人地の設計論理を読夕解く方法論を発展させてきた. まず，近世最大規模の城下町である江戸の町人地を対象 として方法論の礎を築き ${ }^{13)}$, その後, 水路網の発達した 近世城下町大坂の町人地を対象として方法論に改良を加

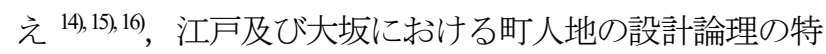
質を読み解いた ${ }^{17)}$.

なお，こうした方法論の詳細については，参考文献に 挙げた既発表論文に譲り，本稿では，この方法論の要点 を表-1にまとめる.

\section{（2）方法論の適用上の課題}

既往研究の方法論においては，近世城下町の設計論理 に関する文献史料の欠落を補うため，明治初期に作成さ れた縮尺 5,000 分の 1 程度の大縮尺の近代測量困を分析 史料として用いる必要がある. 具体的には，表-1におけ る「I. 設計基準」の分析にあたり，「宅地奥行」及び 「街区辺の長さ」を計測するため, さらに「微地形」を 把握するために近代測量困を用いる.

しかし，大坂（大阪）及び江戸（東京）以外の諸都市 においては，明治初期の近代測量図として，陸軍参謀本 部陸地測量部により作成された迅速測困をはじめ, 縮尺 20,000 分の 1 程度の中縮尺の測量困は現存しているが, それらは「宅地奥行」及び「街区辺の長さ」の計測にあ たり，計測誤差 1～2 間程度（京間 1 間 で地図計測を行うには縮尺が小さく，さらに「微地形」 の把握にあたり，分析に必要な 1 尺（う0.303m）程度の 標高差を把握するには，たとえば迅速測図の等高線間隔 は $5 \mathrm{~m}^{18)}$ と広すぎるなど，十分な精度を得ることができ ない.

そのため, 大坂及び江戸以外の城下町に既往研究の方 法論を適用するためには，「宅地奥行」及び「街区辺の 長さ」の計測, さらに「微地形」の把握にあたり, 新た な分析史料を用いるなど, 方法論の改良が必要である. 
表-1 近世城下町町人地の設計論理を読み解くための方法論

\begin{tabular}{|c|c|c|c|}
\hline \multicolumn{3}{|c|}{ 分析視点 } & \multirow{5}{*}{\begin{tabular}{|l} 
・明治初期に作成された大縮尺の近代測量図を用いて, \\
「A. 宅地奥行及び街区辺の長さ」，「B. 街路交差 \\
角」，「C. 堀川と両岸の浜地，街路，宅地のセット」に \\
ついて計測し，モジュール及び設計標準を明らかにする. \\
•そのうえで，宅地奥行及び街区形態に関して，基本とされ \\
るモジュールからの“ずれ” に着目し，“ずれの度合い” \\
や“ずれの要因”について，地形や先行基盤，先行条件な \\
どの設計に影響を与える要素を総合的に分析し，町割に対 \\
してどのような要素が優先していたのか，その優先度を読 \\
み解くことで，町割の基軸や基点を明らかにする.
\end{tabular}} \\
\hline \multirow{4}{*}{ I. 設計基準 } & i. モジュール & $\begin{array}{l}\text { •宅地奥行 } \\
\text { •街区形態 } \\
\text { ・水路と両岸の浜地・街路・宅地 } \\
\text { のセット 等 }\end{array}$ & \\
\hline & ii. 設計標準 & $\begin{array}{l}\cdot \text { 街路幅員 } \\
\text { • 堀川/掘割運河幅員 } \\
\text { ・浜地/河岸地幅員 } \\
\text { ·下水路幅員 等 }\end{array}$ & \\
\hline & iii. 町割の基軸 & $\begin{array}{l}\text { ・町割に際して基準となった軸 } \\
\text { - 街道, 主要街路 } \\
\text { - 水路 } \\
\text { - 方位 等 }\end{array}$ & \\
\hline & iv. 町割の基点 & $\begin{array}{l}\text { ・町割に際して基準となった地点 } \\
\text { - 街道の起点 } \\
\text { - 橋の袂 等 }\end{array}$ & \\
\hline \multirow{2}{*}{\multicolumn{2}{|c|}{ II. 設計単位 }} & $\begin{array}{l}\text { ・設計にあたり, 同一の設計基準 } \\
\text { の下で設計されたと考えられ } \\
\text { る, 一定のまとまりをもった区 }\end{array}$ & $\begin{array}{l}\text { •「A. 宅地奥行及び街区形態のまとまり」，「B. 下水路 } \\
\text { 網のまとまり」，「C. 堀川と両岸の浜地，街路，宅地の } \\
\text { セット」，「D. 間口方向のまとまり」に着目し，それら } \\
\text { の関係を総合的に読み解くことで，同一の設計基淮の下で } \\
\text { 設計されたと考えられる単位を明らかにする. }\end{array}$ \\
\hline & & 域の単位 & $\begin{array}{l}\text { •そのうえで，実際の設計にあたり，設計基淮の諸要素が相 } \\
\text { 互にどのように関係づけられ，即地的に現場に落とし込ま } \\
\text { れていつたのかを読み解く. }\end{array}$ \\
\hline \multicolumn{2}{|l|}{ III. 開発過程 } & $\begin{array}{l}\text { ・個々の設計単位が，どのような } \\
\text { 前後関係で開発されたのかとい } \\
\text { う開発の過程 }\end{array}$ & $\begin{array}{l}\text { • 「A. 街道や主要街路の建設時期と町割との関係」, } \\
\text { 「B. 堀川の開削年次と下水路整備との関係」,「C. 町 } \\
\text { の成立年代」などを読み解くことで, 設計単位間の開発の } \\
\text { 前後関係を明らかにする. }\end{array}$ \\
\hline
\end{tabular}

また，大坂や江戸のような面積規模の大きな町人地で はなく, 比較的面積規模の小さな城下町町人地において, 既往研究の方法論を用いて設計の際の優先度や設計基準 の相互関係を読多解くことができるかどうかといった， 方法論の適用可能性についても検証する必要がある.

\section{(3) 錦見地区の分析にあたっての方法論}

近世城下町岩国の錦見地区の分析にあたっては，既往 研究における方法論（表-1）を適用しつつ, その適用上 の課題を踏まえ, 以下の通り方法論を一部改良する.

まず，城下町岩国では，大坂や江戸のように，明治初 期に作成された大縮尺の近代測量図は現存していない. そこで，「宅地奥行」及び「街区辺の長さ」の分析にあ たっては，1761（宝暦11）年に作成された『錦見町絵困』 （図-2）及び1726（享保 11）年頃に編集された『享保増 補村記』を用いる。『錦見町絵図』は，錦見地区中心部 の町人地に位置する 7 つ町（錦見七町）を描いた大絵 罒で，各宅地の間口及び奥行の寸法が記載されている ${ }^{19)}$. また，『享保増補村記』には，各町の間口の合計の長さ， すなおち街区辺の寸法が記されており 20)，『錦見町絵図』 に記載された寸法を補うことができる。そこで，これら
の寸法を用いて，錦見地区中心部の「宅地奥行」及び 「街区辺の長さ」の分析を行う.

なお，錦見地区中心部の町割（街区構成及び屋敷割） は，江戸前期から現在までほぼ継承されていることが確 認されていることから 21), これらの絵図等に記載された 寸法も，江戸前期から継承されていると考える.

一方，各屋敷の間口及び奥行の寸法が記載された『錦 見町絵図』に類する史料として，大坂においては『水 帳』，江戸においては『沽券図』が存在するが，それら は町人地の一部分しか遺されておらず22,23)，町人地全体 を網羅するものではない. そのため, 大坂及び江戸の分 析にあたっては，近世の絵図ではなく明治初期に作成さ れた近代測量図を分析史料として用いざるを得なかった。

次に,「微地形」の分析にあたっては, 縮尺 1,200 分 の 1 の『岩國町下水道工事平面圖』（以下，下水道図） を用いる. この下水道図は，錦見地区全体の下水道の状 況を示したもので，作成年代は長く見積もって1935（昭 和 10）年から 1948 (昭和 23）年と推定されている ${ }^{24) .}$ この下水道図には，開渠及び暗渠の下水道の位置や集水 区域に加え，0.5 尺単位の等高線が記されており，これ により詳細な微地形を把握することができる. 


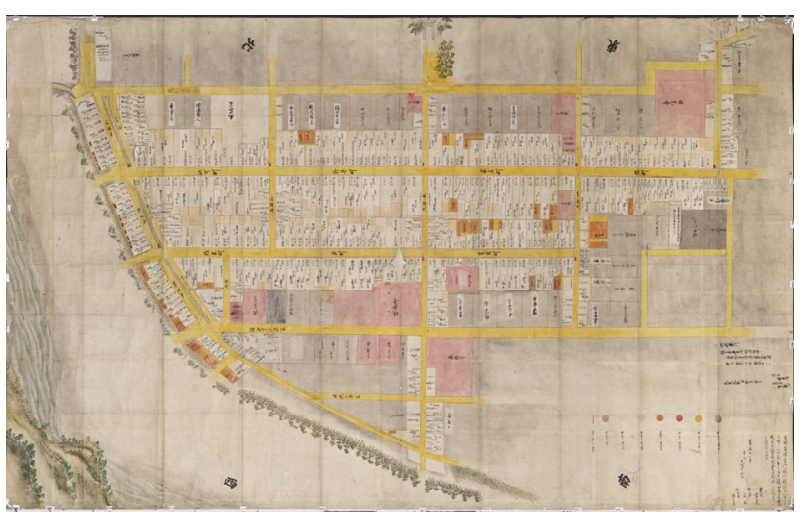

図-2 『錦見町絵図』（1761（宝暦 11）年）

表-2 分析に用いる文献史料

\begin{tabular}{|c|c|c|c|}
\hline 文献名 & 著者 & 出版 & 出版年 \\
\hline \multirow{2}{*}{$\begin{array}{l}\text { 岩国城下町 } \\
\text { 岩国市岩国地区伝統的建造物群 } \\
\text { 保存対策調査報告書 } \\
\text { 岩邑年代記（1）～（11） }\end{array}$} & $\begin{array}{c}\text { 岩国市 } \\
\text { 教育委員会 }\end{array}$ & $\begin{array}{c}\text { 岩国市 } \\
\text { 教育委員会 }\end{array}$ & 2005 \\
\hline & 岩国徵古餙 & 岩国徵古館 & $\begin{array}{c}1984 \sim \\
2000\end{array}$ \\
\hline 享保増補村記 & - & - & 1726 頃 \\
\hline 㟔国市史＼cjkstart史料編一 & $\begin{array}{l}\text { 岩国市史 } \\
\text { 編纂委員会 }\end{array}$ & 岩国市 & $\begin{array}{c}2001 \sim \\
2002\end{array}$ \\
\hline
\end{tabular}

表-3分析に用いる絵図及び地図

\begin{tabular}{|c|c|c|}
\hline 分析内容 & 絵図及び地図名 & 発行年 \\
\hline \hline $\begin{array}{c}\text { 設計単位 } \\
\text { 開発過程 }\end{array}$ & 御領内之図 (岩国領全図) & 1668 (寛文 8) 年 \\
\hline $\begin{array}{c}\text { 設計基準 } \\
\text { 設計単位 }\end{array}$ & 錦見町絵図 & 1761 (宝暦 11) 年 \\
\hline $\begin{array}{c}\text { 設計単位 } \\
\text { 開発過程 }\end{array}$ & 岩国領全図 (三之中) & 1866 (慶応 2) 年 \\
\hline $\begin{array}{l}\text { 設計単位 } \\
\text { 開発過程 }\end{array}$ & 岩国城下町 (錦見) & 1867 (慶応 3) 年 \\
\hline 微地形 & 岩國町下水道工事平面圖 & $\begin{array}{c}1935 \text { (昭和 10) } \\
1948 \text { (昭和 23) 年頃 }\end{array}$ \\
\hline
\end{tabular}

なお，前述の通り，錦見地区中心部の町割は，江戸前 期から現在まで継承されていることから ${ }^{25}$ ，街区形態同 様，中心部の微地形についても大きな変化があったとは 考え難い[1].つまり，この下水道図に記された等高線は， 近世の錦見地区の微地形を把握するうえで有効であると 考える. 一方，この下水道図に記載された等高線は，た とえば 16.5 尺の標高を示寸等高線に隣接して 18.0 尺の標 高を示す等高線が記されるなど，等高線が一部省略され ている箇所があることから，そうした省略されている等 高線を適宜補いつつ「微地形」の分析を行う.

これらのほか，「設計単位」及び「開発過程」の分析 にあたっては，表-2に示す文献史料により各町の単位や 成立年代を把握したうえで，表-3に示寸各年代の絵図に よりその範囲を確認する.

\section{3. 分析結果}

\section{（1）錦見地区の都市構造}

錦見地区は，錦帯橋の袂を北西端として，そこから南 東方向へ広がる細長い地区である（図-3）。地区西部に 位置する錦見七町 (町人地) をコの字に囲むように, 中 下級武士の屋敷（武家地）が配置されている. また，地 区東部にも中下級武士の屋敷が配置されている.

町人地においては, 北西 - 南東方向を長辺とする長方 形街区による町割がなされ，さらに町人地の周囲の武家 地においても，町人地と連続するように長方形街区によ る街区割がなされている，敷地の間口は，基本的には街 区長辺に設けられたが，各横町においては，一部分街区 短辺に間口を設けている敷地もある。

街路網は, 城一向かう北西 - 南東方向の街路が主要街 路であり，その最も北東側が中級武士の屋敷が並ぶ武家 地を通る「大明小路」で, そこから順に南西へ, 町人地 のメインストリートである「本町通り」，同じく町人地 を通る「材木町筋」，さらに武家地を通る「瑞相寺小路」 が配置されている．また，大明小路の南東側の延長には， 今津地区へと通ずる「善教寺小路」及び「新小路」が配 置されている.

錦見地区では，これらの主要街路への街道 (山陽道) の引込みはなく, さらに錦川からの水路の引込みもない.

\section{（2）設計基準に関する分析結果}

\section{a) 街区形態 (図-3，4）}

錦見地区中心部の街区形態に関する分析結果は，以下 のとおりである，なお，図-4 は，『錦見町絵図』(1761 （宝暦 11）年）模写 ${ }^{20}$ 及び『岩国城下町（錦見）』 （1867（慶応 3）年）模写 27をべース図として，『錦見 町絵図』（1761（宝暦11）年）及び『享保増補村記』を 基に街区辺の長さ及び宅地奥行を記載したものである.

\section{○街区形態の基本}

既存文献 28)によると，錦見地区の中心部は，60間 $\times 30$ 間の長方形街区を基準とする町割が行われたとされてい る.たしかに，錦見地区西部では，おおよそ基準に則っ た 60 間 $\times 30$ 間の長方形街区が，北西から南東方向に整 然と配置されているように見える。しかし，それらの街 区形態を詳細に分析すると，街区形態の基準からのずれ を見出すことができる.

○街区長辺

・錦見地区中心部の町人地及びその周辺の武家地におい て, 北西 - 南東方向の街区辺（街区長辺）に着目して みると, 上横町の南東側の街区（柳井町, 魚町）は 61 62 間, 中横町の南東側の街区 (米屋町, 豆腐町) は約 60〜61 間で，概ね基準通りではあるが，上横町 の南東側の街区のほうが若干長くなっている. 


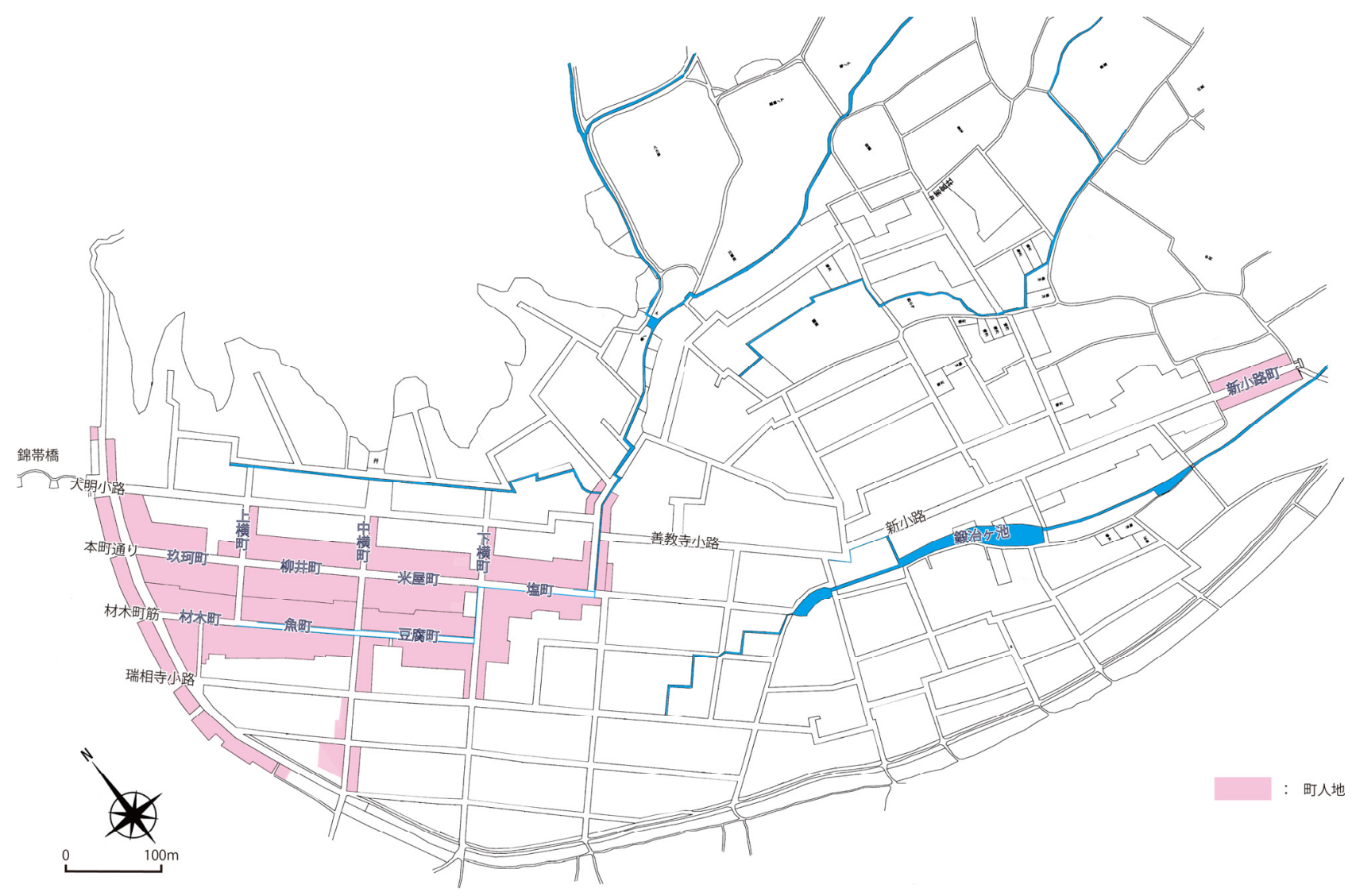

図-3 錦見地区全体図（『岩国城下町（錦見）』（1867（慶応 3）年）をトレース）

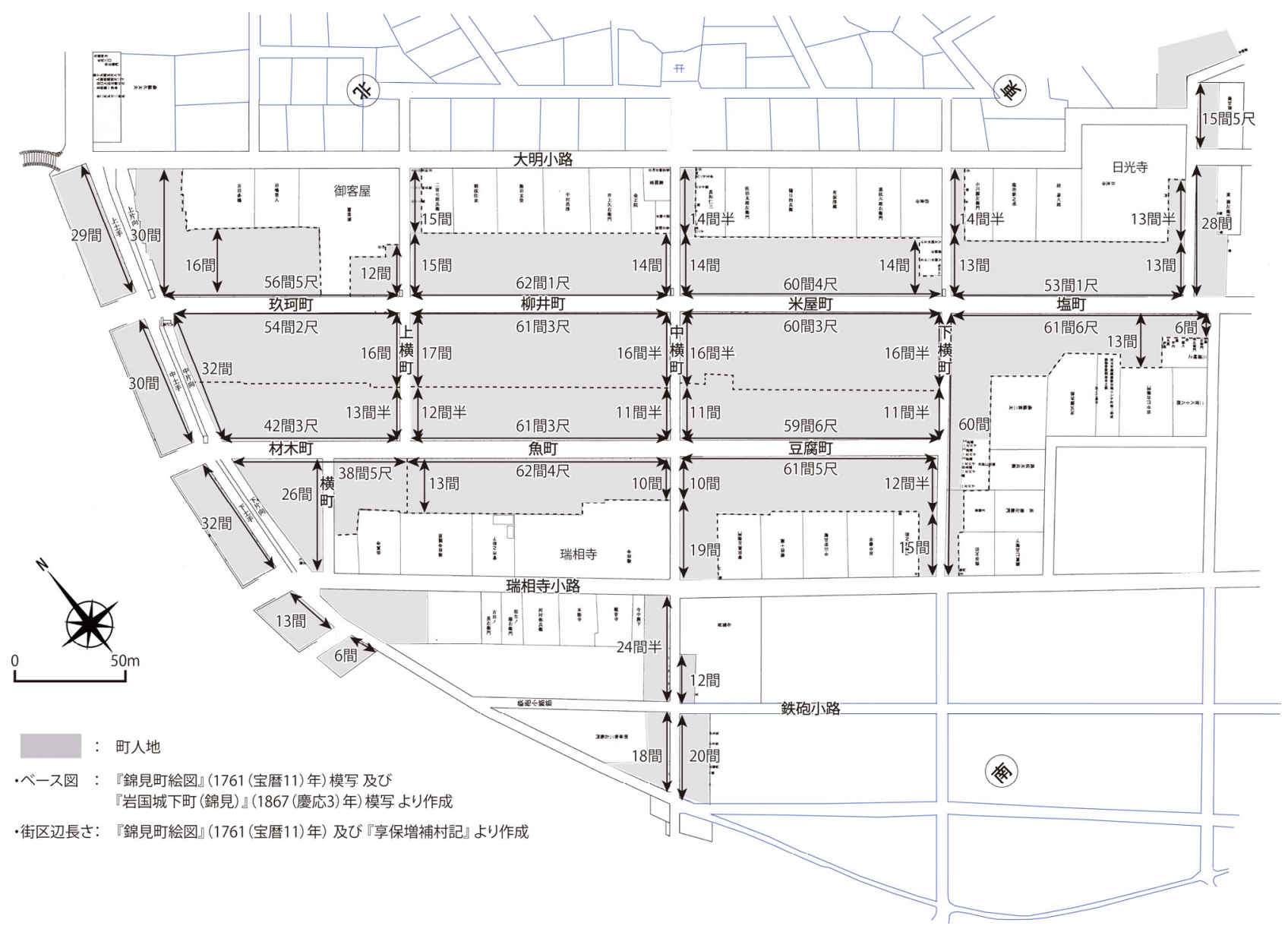

図-4 街区形態及び宅地奥行の分析図 
・一方，下横町の南東側の街区（塩町）は，塩町の北東 側が 53 間 1 尺，南西側が 61 間 6 尺と，街路の両側で 長さが大きく異なっている.

・錦川沿いの上横町の北西側の街区（玖珂町，材木町) は, 錦川の湾曲に沿うように, 街区辺の長さも玖珂町 の両側で 54〜 56 間，材木町の両側で 39〜42 間と，下 流方向に向けて徐々に短くなっている.

\section{○街区短辺}

・錦見地区西部の町人地及びその周辺の武家地において, 北東 - 南西方向の街区辺（街区短辺）に着目してみる と, 大明小路の南西側街区及び本町通りの南西側街区 の短辺は，南東に向かうにつれて徐々に 30 間よりも 短くなっている.

-一方，材木町筋の南西側街区では，中横町の南東側街 区の短辺が 29 間と最長で，錦川沿いの横町の北西側 街区や下横町の北西側街区の短辺はそれよりも短く なっている.

-中横町の両側の街区短辺に着目寸ると，北東端から錦 川に近づくにつれて街区短辺が短くなる傾向にあるが， 材木町筋の南西側街区のみ 29 間と他と比べて長く なっている.

○不整形街区

・錦見地区西部の大明小路は，下横町との交差点から南 東に進み, 日光寺の敷地を回り込むようにいったん北 東に屈折したあと，再び南東に屈折している，そのた め, 塩町の北東側の街区形態が不整形となっている.

・材木町筋は, 豆腐町から南東方向には延びておらず, 豆腐町の南東端で突当りの丁字路になっている. その ため, 材木町筋の突当りの街区形態が $\mathrm{L}$ 字型の不整形 となっている.

・上横町は, 材木町筋で突当りの丁字路になっており, 横町も同様に材木町筋で突当りの丁字路になっている. そのため, 材木町筋の南西側で横町の南東側の街区は, 街区長辺が他の街区と比較して極端に長くなっている.

・錦見地区北東部の街区形態は, 地区の北東から張り出 す山地の地形に合わせるように不整形となっている.

・錦川沿いでは, 河川の湾曲にあわせるように街路が屈 曲しており，そのため街区形態が不整形となっている. ・錦見地区東部では，丁字路や L 字路が多数存在し，さ らに鍛冶ヶ池付近では河川の流路に沿って街路が屈曲 しているため，街区形態が不整形となっている.

○分析結果のまとめ

このように，錦見地区西部の町人地及びその周辺の武 家地では，街区長辺及び街区短辺ともに，基準とされて いる 60 間 $\times 30$ 間の長方形街区からのずれがみられる.

これは，町割にあたり，街路を平行に敷設して基準に 則った街区を配置することよりも，他の何らかの要因を 優先したためであると考える.
一方，錦見地区の北部及び東部，さらに錦川沿いでは， 街路が格子状に配置されておらず，そのため基準に則ら ない不整形街区が多数発生している，これは，錦見地区 西部と同様に，町割にあたり，格子状に街路網を敷設す ることよりも，他の何らかの要因を優先したためである と考える.

こうした町割にあたり，基淮に則った街区を配置する ことに優先する要因については, 他の分析結果とあわせ て考察する.

\section{b) 宅地奥行 (図-4)}

錦見地区中心部の宅地奥行に関する分析結果は，以下 のとおりである.

○間口方向

- 錦見地区中心部の宅地は，基本的に城一向かう北西 南東方向の街路に面する街区長辺に間口を向けた両側 町となっている. また, 街区の長辺方向と平行に, 街 区の中央部に宅地境界の背割線が通されている.

・一方, 城へ向かう街路に直交する街路（横町）沿いに は，横町に間口を向けた宅地も存在する.

○大明小路沿いの敷地奥行

・錦帯橋へと続き，中級武士の屋敷地を通る大明小路の 両側には, 間口約 10 間, 敷地奥行約 15 間の武家屋敷 が整然と配置されている ${ }^{29}$.

○本町通り沿いの宅地奥行

・本町通りの玩珂町では, 両側に奥行約 16 間の宅地が 配置されている. なお，玫珂町の北東側の街区で，上 横町との交差点付近の宅地は奥行が約 12 間と短く なっているが，これは，同じ街区で背割線を介して隣 接寸る大明小路側の御客屋（藩客を応接寸る施設）の 敷地を確保することを優先したためであると考える.

- 本町通りの柳井町では，北東側は奥行約 $14 \sim 15$ 間， 南西側は奥行約 16 間半〜 17 間の宅地が配置されてお り, 北東側に比べ南西側のほうが宅地の奥行が長く なっている.

・本町通りの米屋町では，北東側は奥行約 14 間，南西 側は奥行約 16 間半の宅地が配置されており，北東側 に比べ南西側のほうが宅地の奥行が長くなっている.

・本町通りの塩町では, 両側に奥行約 13 間の宅地が配 置されており, 本町通りの他の町に比べて宅地の奥行 が短くなっている. 特に, 塩町の南側の街区で武家地 と隣接する宅地では, 最も短いところでは奥行が約 6 間となっている.こうした塩町の宅地奥行は，同じ街 区で背割線を介して隣接する武家屋敷の奥行を確保寸 ることを優先したために短くなっていると考える.

○材木町筋沿いの宅地奥行

・材木町筋の材木町では, 両側に奥行約 12〜13 間半の 宅地が配置されており, 本町通りと比べて宅地の奥行 が短くなっている. 
表-4 秀吉及び家康により建設された主な城下町の街区形態及び宅地奥行

\begin{tabular}{|c|c|c|c|c|}
\hline 建設開始年次 & 城下町名 & 建設大名 & 街区形態 & 宅地奥行 \\
\hline 1574（天正 2） & 長浜 30 33) & 羽柴秀吉 & 長方形街区 & - \\
\hline 1577 (天正 5) & 浜松 34 36) & 徳川家康 & - & - \\
\hline 1583 (天正 11) & $\begin{array}{l}\text { 大坂 37r 40) } \\
\text { (平野町・島町) }\end{array}$ & 羽柴秀吉 & 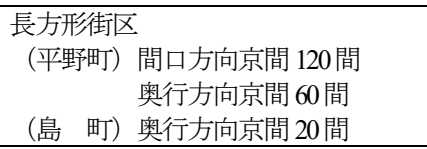 & 奥行京間 20 間 \\
\hline 1584 (天正 12) & 福知山 ${ }^{41342)}$ & 羽柴秀勝 & - & - \\
\hline 1585 (天正 13) & 近江八幡 (3) -47) & 羽柴秀次 & $\begin{array}{l}\text { 長方形街区 } \\
\text { 間口方向京間 } 70 \text { 間 } \\
\text { 奥行方向京間 } 45 \text { 間 }\end{array}$ & 奥行京間 22.5 間 \\
\hline 1585 (天正 13) & 大和郡山 $\left.{ }^{48} \sim 53\right)$ & 羽柴秀長 & 長方形街区 & 奥行京間約 12 間 \\
\hline 1585 (天正 13) & 和歌山 ${ }^{54,55)}$ & 羽柴秀吉 & - & - \\
\hline 1585（天正 13） & 大坂（上町） & 羽柴秀吉 & 長方形街区 & 奥行京間 13 間〜14間 \\
\hline 1590（天正 18） & 京都 50) (2)（天正新地割） & 豊臣秀吉 & $\begin{array}{l}\text { 京間 } 60 \text { 間四方正方形街区の中央に } \\
\text { 南北方向に街路を通し長方形街区に }\end{array}$ & $\begin{array}{l}\text { (京間 } 60 \text { 間一南北方向街路幅員) } \\
\times 1 / 4 \fallingdotseq \text { 奥行京間 } 15 \text { 間以下 }\end{array}$ \\
\hline 1594 (文禄 3) & 伏見 ${ }^{(3)}$-67) & 豊臣秀吉 & $\begin{array}{l}\text { 長方形街区 } \\
\text { 間口方向約 } 120 \mathrm{~m} \text { (京間約 } 60 \text { 間) } \\
\text { 奥行方向約 } 60 \mathrm{~m} \text { (京間約 } 30 \text { 間) } \\
\end{array}$ & $\begin{array}{l}\text { (奥行方向京間約 } 60 \mathrm{~m}) \times 1 / 2 \doteqdot \\
\text { 奥行京間約 } 15 \text { 間 }\end{array}$ \\
\hline 1598 (慶長 3) & 大坂 $($ 船場・島之内・下船場) & 豊臣秀吉 & 京間 40 間四方正方形街区 & 奥行京間 20 間 \\
\hline 1601 (慶長 6) & 膳所 $(8)(\theta)$ & 徳川家康 & - & - \\
\hline 1601 (慶長 6) & 加納 70$)$ & 徳川家康 & - & - \\
\hline 1603（慶長 8) & 江戸 & 徳川家康 & $\begin{array}{l}\text { 京間 } 60 \text { 間四方正方形街区 } \\
\text { 中央京間 } 20 \text { 間四方会所地 }\end{array}$ & 奥行京間 20 間 \\
\hline 1607 (慶長 12） & 駿府 71 〜7) & 徳川家康 & $\begin{array}{l}\text { 京間 } 50 \text { 間四方正方形街区 } \\
\text { 中央京間 } 10 \text { 間四方会所地 }\end{array}$ & 奥行京間 20 間 \\
\hline 1609 (慶長 14) & 名古屋 TI -81) & 徳川家康 & $\begin{array}{l}\text { 京間 } 50 \text { 間四方正方形街区 } \\
\text { 中央京間 } 10 \text { 間四方会所地 }\end{array}$ & $\begin{array}{l}\text { 奥行京間 } 20 \text { 間 } \\
\text { 角地は奥行京間 } 15 \text { 間 }\end{array}$ \\
\hline 1609 (慶長 14） & 篠山 ${ }^{82}$ ～84) & 徳川家康 & - & - \\
\hline
\end{tabular}

・材木町筋の魚町では，両側に奥行約 10〜13 間の宅地 が配置されている.

•魚町の南西側の街区で，中横町との交差点付近の宅地 は奥行が 10 間と短くなっているが，これは，同じ街 区で背割線を介して隣接する瑞相寺の敷地を確保する ことを優先したために短くなっていると考える.

・材木町筋の豆腐町では，北東側は 10〜11 間半，南西 側は $12 \sim 13$ 間半と, 北東側に比べ南西側のほうが宅 地の奥行が長くなっている.

○瑞相寺小路沿いの敷地奥行

・瑞相寺小路沿いには，敷地奥行約 15 間の武家屋敷が 配置されている ${ }^{85}$.

○分析結果のまとめ

このように，錦見地区中心部の町人地及びその周辺の 武家地では，街区辺，特に街区短辺の長さが一定ではな いことから，町人地の宅地奥行は均一ではない. 一方, 武家屋敷の敷地奥行は 15 間でほぼ一定している。また， 本町通りでは，街路の南西側の宅地奥行のほうが北東側 の宅地奥行よりも最大で 2 間半程度長いのに対し，材木 町筋では，本町通りに比べ，街路を挟んだ両側（両側町） の宅地奥行のばらつきは小さい.

ここで，1574（天正 2）年に建設が始まった城下町長 浜以降，複数の城下町を建設した秀吉及び家康が携わつ た主な城下町の街区形態及び宅地奥行の系譜を整理した ものが表-4である.
これを見ると，宅地奥行に関しては，様々な宅地奥行 が模索される中で，大坂の船場地区以降，奥行京間 20 間に落ち着いていった過程を読み取ることができる。つ まり，京間 15 間という岩国の宅地奥行は，城下町町人 地の宅地奥行としては比較的短く，これは，城下町面積 の狭さが宅地奥行の短さに影響した可能性がある。同様 に，背割線を介して同一街区に武家屋敷と町屋が混在し ている点も, 城下町面積の狭さを反映した岩国の特徽で あると考える.

これらのことから, 宅地奥行に関して以下のように分 析することができる.

敷地割にあたつては，まず，町人地の宅地に優先して， 大明小路沿い及び瑞相寺小路沿いの武家屋敷の敷地奥行 15 間を確保する。 そのため, 武家屋敷と背割で接する 町人地の宅地奥行は, 街区短辺の長さから武家屋敷の奥 行 15 間を差し引いた長さとなる. その結果，材木町筋 の南西側の宅地は，背割線を介して隣接する武家屋敷と の取り合いで奥行が 15 間よりも短くなる. 一方，材木 町筋の北東側の宅地は, 南西側の宅地と概ね同じ長さ, つまり奥行が 15 間よりも短くなる.

これに対して, 本町通りの南西側の宅地は, 背割線を 介して隣接する材木町筋の北東側の宅地との取り合いで, 奥行が 15 間よりも若干長くなるが，北東側の宅地は背 割線を介して隣接する武家屋敷との取り合いで，奥行き が概ね 15 間程度となる。 
なお，本町通り沿いよりも材木町笳沿いの宅地のほう が，街路の両側で奥行にばらつきが小さい理由について は明確ではないが，材木町筋よりも本町通りのほうが町 人地における主要な街路であったことを踏まえると，本 町通り沿いの宅地のほうが奥行が長くなるよう配慮した 可能性がある.

一方，玖珂町の北東側街区の上横町との交差点付近の 宅地や塩町の南西側街区の武家地と隣接する宅地，さら に魚町の南西側街区の中横町との交差点付近の宅地に顕 著に見られるように，背割線を介して隣接寸る藩の主要 施設や武家屋敷，あるいは寺院の敷地の影響を受けて, 極端に奥行の短い宅地も存在する.

c) 町割の基軸（図-5, 6)

錦見地区の町割の基点・基軸については，街路網と微 地形との関係に着目して分析を行う。分析結果は, 以下 のとおりである. なお，図-5，6 に示寸等高線は，『岩 國町下水道工事平面圖』に記載された標高データに基づ き，同図の等高線を追記・修正したものである.

○地区全体の微地形の傾向

・錦見地区は，全体的に北西側の標高が高く，南東方向 に向けて標高が低くなっている.

・微地形の特徴として, 地区内には尾根筋や谷筋, 窪地 といった地形の起伏が存在する.

○北西 - 南東方向の街路

・城へ向から北西 - 南東方向の街路に着目してみると, 本町通りは，微低地である谷筋を通り，下横町との交 差点付近では窪地を通っている.

・大明小路は，北西端では本町通りと 30 間間隔を保っ ているが，南東に向かうにつれて本町通りと下横町と の交差点付近の窪地に近づいており，そのため南東に 向かうにつれて本町通りとの間隔を徐々に狭めている。 ・材木町筋は，概衫微高地である尾根筋を通っている. 特に顕著であるのは下横町との交差点付近で, 窪地と 䆶地に挟まれた微高地を通っている。 こうした微高地 に沿うように，南東に向かうにつれて本町通りとの間 隔を徐々に狭めている.

・瑞相寺小路は，微低地である谷筋を通っており，下横 町との交差点付近，及び塩町の東側の横町との交差点 付近では窪地を通っている。これに伴い，瑞相寺小路 は，北西端から中横町との交差点に向けて材木町筋と の間隔を徐々に広げたあと，そこから南東に向かうに つれて材木町筋との間隔を徐々に狭めている.

・大明小路の延長にあたる新小路は，微低地にあたる鍛 治ヶ池を避けつつ，微高地をたどるようにして東へと 屈曲している.

○北東 - 南西方向の街路

・次に，城一向かう街路と直交する北東 - 南西方向の街 路に着目してみると，下横町は，本町通りとの交差点
表-5 北西 - 南東方向の各街路の平均縦断勾配

\begin{tabular}{|c|c|c|c|c|c|}
\hline 街路名 & $\begin{array}{c}\text { 基点 } \\
\text { 標高*1 }\end{array}$ & $\begin{array}{c}\text { 終点 } \\
\text { 標高*2 }\end{array}$ & 標高差 & $\begin{array}{l}\text { 起終点 } \\
\text { 延長 }\end{array}$ & $\begin{array}{l}\text { 平均 } \\
\text { 縱断 } \\
\text { 勾配 }\end{array}$ \\
\hline 大明小路 & 23.00 尺 & 20.25 尺 & $\begin{array}{c}2.75 \text { 尺 } \fallingdotseq \\
0.833 \mathrm{~m}\end{array}$ & $252 \mathrm{~m}$ & $0.331 \%$ \\
\hline 本町通り & 24.25 尺 & 19.75 尺 & $\begin{array}{c}4.50 \text { 尺 } \fallingdotseq \\
1.364 \mathrm{~m}\end{array}$ & $370 \mathrm{~m}$ & $0.369 \%$ \\
\hline 材木町筋 & 24.25尺 & 21.00 尺 & $\begin{array}{c}3.25 \text { 尺 } \fallingdotseq \\
0.985 \mathrm{~m} \\
\end{array}$ & $335 \mathrm{~m}$ & $0.294 \%$ \\
\hline 瑞相寺小路 & 23.25 尺 & 20.00 尺 & $\begin{array}{c}3.25 \text { 尺 } \\
0.985 \mathrm{~m}\end{array}$ & $296 \mathrm{~m}$ & $0.333 \%$ \\
\hline
\end{tabular}

*1 各街路の基点は，錦川沿いの街路との交差点とした．ただし，大 明小路については，錦川沿いの街路との交差点付近から南東方向 に向かっていったん勾配が上がり, その後, 上横町との交差点付 近から下横町との交差点に向けて勾配が下がりはじめることか ら，基点を上横町との交差点とした. なお，等高線間隔が 0.5 尺で あることから，等高線間に基点がある場合には，目視により 0.25 尺単位で標高を読むこととした。

*2 各街路の終点は, 下横町との交差点とした。 なお，等高線間隔が 0.5 尺であることから，等高線間に終点がある場合には，目視によ り 0.25 尺単位で標高を読むこととした。

付近の窪地と, 瑞相寺小路との交差点付近の窪地を貫 くように通っている.

・塩町の南東側の横町も，瑞相寺小路との交差点付近の 窪地を貫くように通っている.

・本町通りの南東端で本町通りと交差する街路も，窪地 を貫くように屈曲して通っている.

・中横町は, 椎尾八幡宮の参道の延長線上に位置寸る街 路であるが，特に微地形との関係は見いだせない．椎 尾八幡宮の創建は錦見地区の町割後であることから， 神社の参道の位置が町割に影響を及ぼしたのではなく， 町割にあわせるように参道の位置が決められた可能性 がある。

・上横町は，中横町と同様に，微地形との関係は見いだ せない。

○分析結果のまとめ

このように，街路網と微地形との関係に着目してみる と，まず，方位とは無関係に，地形の起伏に沿って街路 網を配置していることがわかる，具体的には，北西から 南東方向に向けて緩やかに低くなる傾斜に沿うように, 城へ向かう北西 - 南東方向の街路を配置している. その 際, 谷筋や尾根筋, 宔地といった微地形に配慮して, 街 区幅（街区短辺）の基準である 30 間間隔を柔軟に変化 させながら街路を配置している. 特に, 町人地のメイン ストリートである本町通りは，顕著な谷筋を通っている。 さらに, これらの北西 - 南東方向の街路には街区長辺及 び宅地の間口が向けられ，いずれも地区の主要街路と なっている.

こうした北西 - 南東方向の各街路の平均縦断勾配を算 出してみると，表-5のようになる，わずかな差ではある が，谷筋にあたる本町通りの縦断勾配が最も大きく，次 いで同じく谷筋の瑞相寺小路，続いて大明小路の縦断勾 配が大きい，一方，尾根筋にあたる材木町筋の縦断勾配 は最も小さい結果となった. 


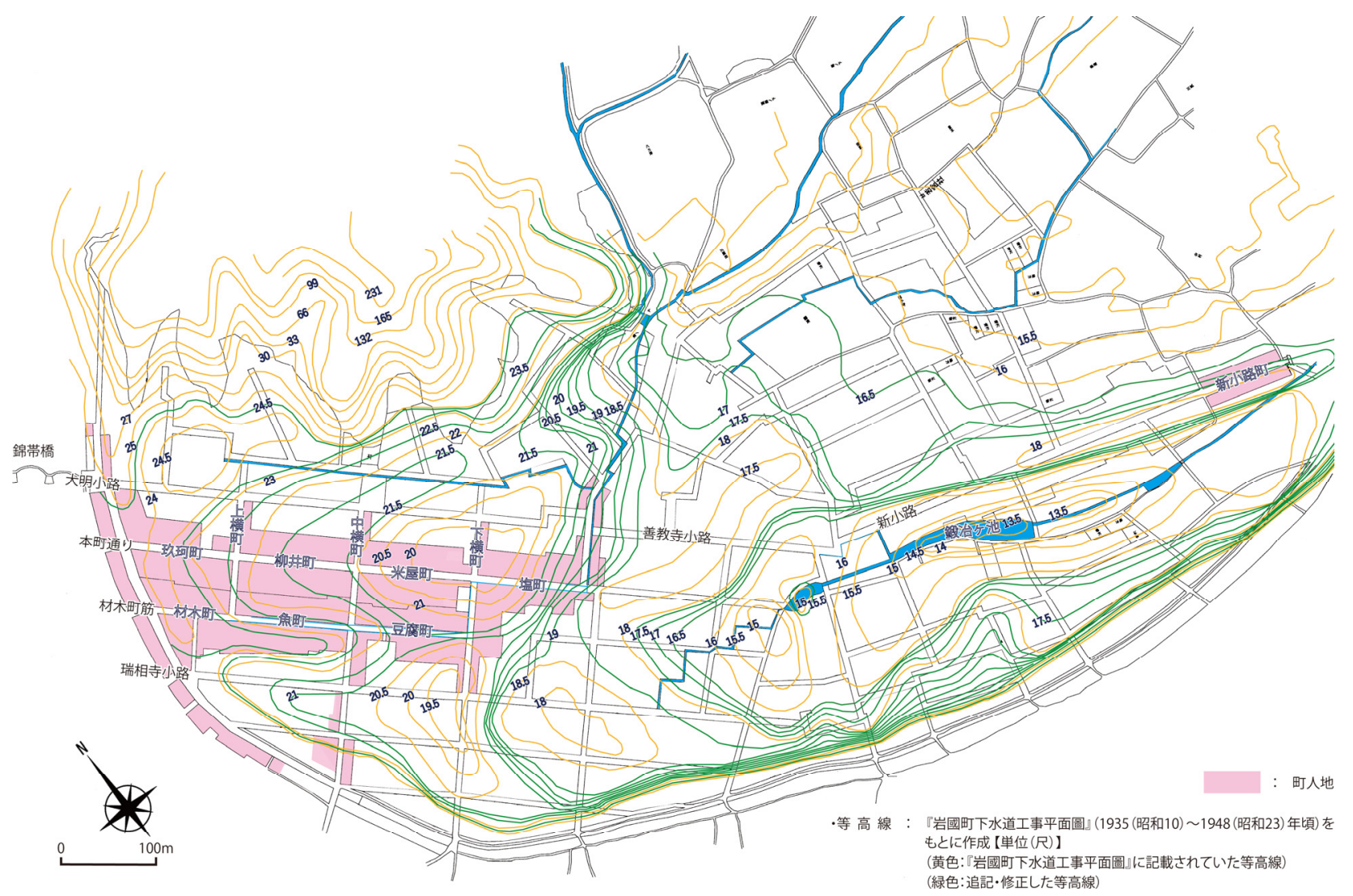

図-5＼cjkstart町割の基軸の分析図（錦見地区全体）

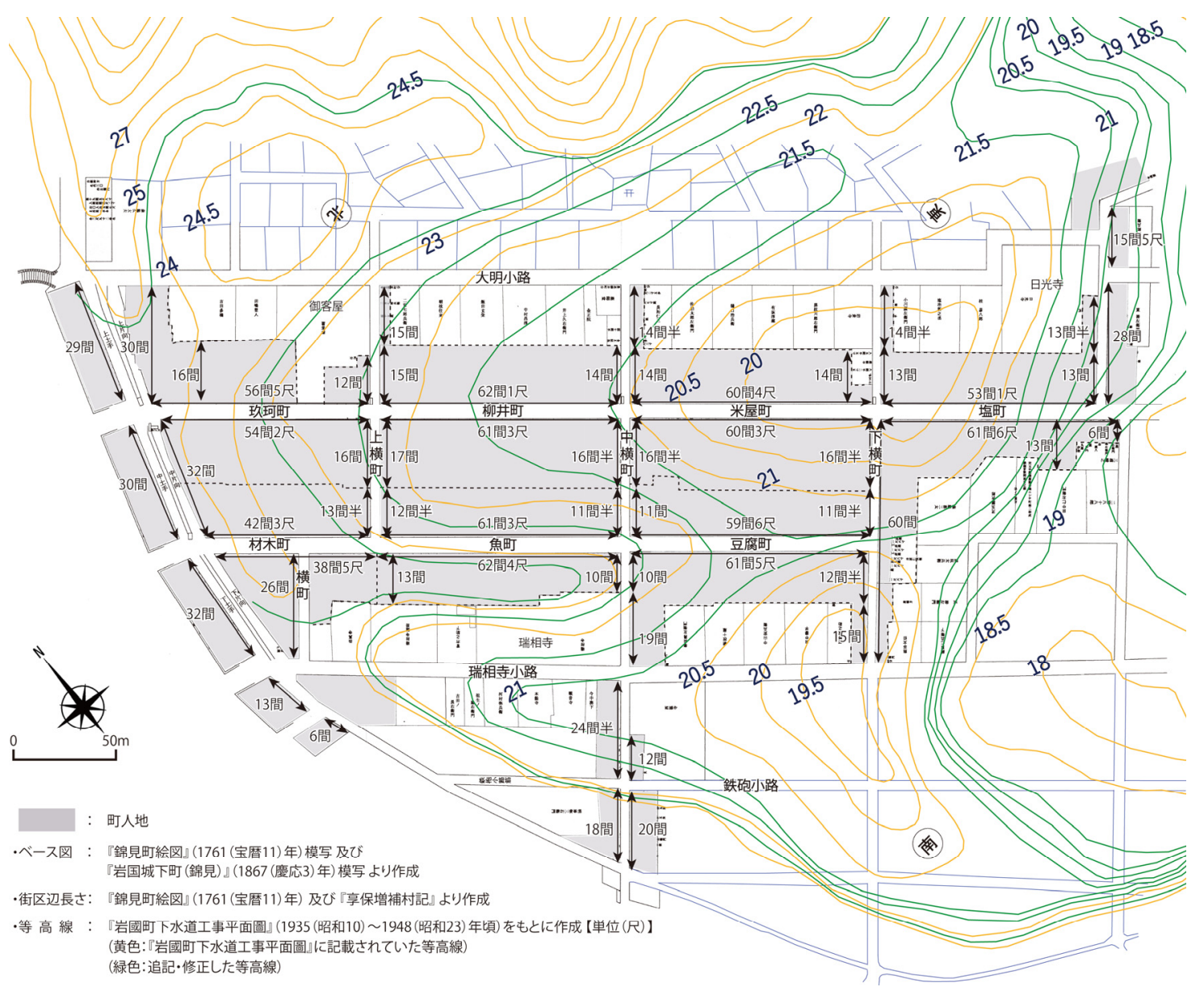

図-6 町割の基軸の分析図（錦見地区中心部） 
次に，城一向かう街路と直交する北東 - 南西方向の街 路は，窪地と窪地をつなぐように下横町が通り，その他 にも窪地を通る街路はあるものの，上横町及び中横町に ついては微地形との関係を見いだせない.

また，河川沿いや地区東部においては，地形条件がよ り厳しくなることから，地形の起伏にあわせて不規則な 街路網となっている.

これらのことから，町割の基軸に関して以下のように 分析することができる.

地区全体としては，町割にあたり，方位や街区の基準 （60 間 $\times 30$ 間の長方形街区）に則ることよりも，微地 形に配慮して街路網を配置している，そのため，基準か らずれた不整形街区が多数発生している.

地区中心部では，まず谷筋に本町通りを通し，これを 基軸として概ね 30 間間隔で平行に, 城一向かう北西 南東方向の街路を配置している. その際, 街区短辺の基 準である 30 間間隔に厳密に則るのではなく，微地形に 配慮して街路と街路の間隔を柔軟に変化させている. 次 に，崔地と窪地をつなぐように下横町を通し，これを基 軸としてほぼ 60 間間隔で平行に, 城へ向かう街路と直 交する北東 - 南西方向の街路を配置している.

大坂や江戸の町人地においても，方位や街区の基準よ りも微地形を優先した町割が行われている ${ }^{80}$. これは, 雨水の排水勾配を確保するためであり, 街路側溝や背割 下水を通して，自然流下による雨水排水を行っていた当 時, 排水勾配の確保は町割において最優先すべき要素の 一つであった，つまり，錦見地区においても，雨水排水 に配慮して，表-5に示寸排水勾配を確保するため，微低 地 (谷筋) や微高地 (尾根筋) といった微地形を優先し た町割が行われたと考える.

\section{（3）設計単位及び開発過程に関する分析結果}

錦見地区の設計単位及び開発過程に関しては，表-2に 示す文献に基づき開発過程を整理するとともに，表-3に 示寸絵図及び地図に基づき設計単位を明らかにした。

まず，吉川広家入封直後の 1600 年代初頭に，錦見七 町及びその周囲の中下級武士の屋敷が一体的に設計・開 発された. その後, 1640 年代に入り, 武家屋敷及び町人 地が拡張され，今津へと続く錦見地区東部の武家地及び 町人地や，錦川沿いの町人地が設計・開発された.さら に, 錦帯橋架橋後の 1690 年頃までに, 地区北東部の武 家地が設計・開発された。

こうした分析結果を表-6及び図-7に示す。これらから， 1600 年代初頭に錦見中心部の町割が行われたのち, 錦川 沿いや今津へと続く地区東部へと市街地が徐々に拡張さ れた様子を把握することができる.
表-6 城下町岩国の開発過程に関わる年表

\begin{tabular}{|c|c|c|}
\hline 西暦 & 和暦 & 主な出来事 \\
\hline 1309 & 延慶 2 & 大内弘幸によって永興寺創建 \\
\hline 1600 & 慶長 5 & $\begin{array}{l}\text { 関ヶ原の戦い, 吉川広家が毛利氏より周防国 } \\
\text { 久我郡・大島郡の内から } 3 \text { 万石を分知される }\end{array}$ \\
\hline 1601 & 慶長 6 & $\begin{array}{l}\text { 横山の城地選定, 横山・錦見・川西・今津の } \\
\text { 屋敷割・町割案作成, 錦川築堤 }\end{array}$ \\
\hline 1602 & 慶長 7 & 横山・錦見・川西・今津の屋敷割・町割実施 \\
\hline 1603 & 慶長 8 & 岩国城起工 \\
\hline 1608 & 慶長 13 & 岩国城竣工 \\
\hline 1615 & 元和元 & 一国一城令により岩国城破却 \\
\hline 1626 & 寛永 3 & 城下町の氏神椎尾八幡宮造営 \\
\hline $\begin{array}{c}1643 \\
\text { 頃 }\end{array}$ & 寛永 20 & $\begin{array}{l}\text { 武家屋敷拡張（散畠（錦見）・新小路（錦 } \\
\text { 見）・川西面田など） }\end{array}$ \\
\hline 1648 & 慶安元 & $\begin{array}{l}\text { 町辺拡張（川原町（横山）・土手町（錦 } \\
\text { 見）・今津町など），錦見新小路町割 }\end{array}$ \\
\hline 1654 & 承応 3 & $\begin{array}{l}12 \text { 月に錦見町の大火事 (寺院 } 3 \text { 軒, 家中屋敷 } \\
20 \text { 軒を含む } 229 \text { 軒焼失) }\end{array}$ \\
\hline 1655 & 明暦元 & 町割一部改正（横町の街路拡幅） \\
\hline 1657 & 明暦 3 & $\begin{array}{l}\text { 横山・錦見間に架橋（1659（万治 2)年流 } \\
\text { 出），横山側では錦見渡橋，錦見側では横山 } \\
\text { 渡橋と呼ばれる }\end{array}$ \\
\hline 1661 & 寛文元 & $\begin{array}{l}\text { 中津（錦川が分岐した門前川のほとり）に別 } \\
\text { 邸，武家屋敷，町屋敷配置 }\end{array}$ \\
\hline & 寛文中 & 川西に町屋敷を新設 \\
\hline 1673 & 延宝元 & 吉川広嘉によって錦帯橋創建 \\
\hline 1684 & 貞享元 & 川西町拡張 \\
\hline 1690 & 元禄 3 & $\begin{array}{l}\text { 錦見の武家屋敷拡張（森木・新道・小道・牢 } \\
\text { 小路など） }\end{array}$ \\
\hline 1692 & 元禄 5 & 横山仙石原・万谷に多聞を建設 \\
\hline 1698 & 元禄 12 & 横山に仙鳥館（別邸）建築 \\
\hline 1712 & 正徳 2 & $\begin{array}{l}\text { 前年に錦見鉄砲小路以東の大火あり，この年 } \\
\text { に小路を付け替え }\end{array}$ \\
\hline 1721 & 享保 6 & 博労屋を塩町より土手町に移転 \\
\hline 1767 & 明和 4 & 新町創設（安永 7年町部に登録） \\
\hline 1787 & 天明 7 & 錦見中横町延長，町部となる \\
\hline 1853 & 嘉永 6 & 豆腐町を登富町と改称 \\
\hline
\end{tabular}

\section{4. 錦見地区の設計論理の考察}

以上の分析結果に基づき，以下の通り，錦見地区にお ける城下町設計の論理を考察する.

○街区の設計基準

・最初期に開発された地区中心部では, 地形の起伏が比 較的緩やかであることから，60 間 $\times 30$ 間の長方形街 区を基準として, 雨水排水に配慮しつつ, 谷筋や尾根 筋といった微地形に応じて基準からの寸法を柔軟に変 化させながら, 城一向かう街路に長辺を向けて比較的 整然と街区が配置された.

・一方，市街地の拡張に伴って開発された地区東部は, 地形の起伏が複雑であり，そうした地形の影響を受け て街路が配置されたため，基準に則らない不整形街区 が多数配置された. 


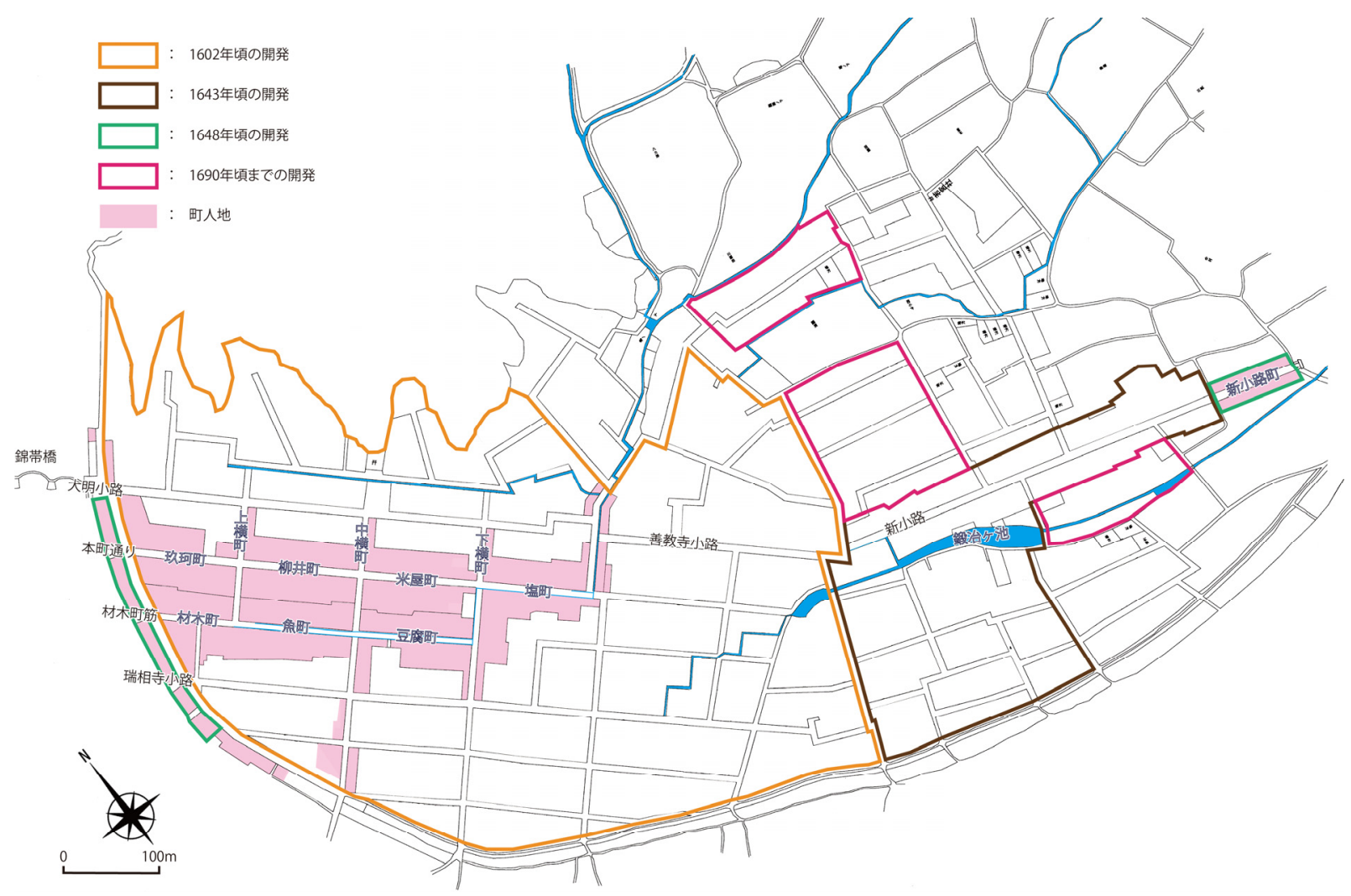

図-7 設計単位及び開発過程の分析図

\section{○町割の基軸}

・街路の配置にあたっては，方位に則ることよりも，雨 水排水のために微地形への配慮を優先させた.

・城へ向かう街路は，南東方向に向けて緩やかに低くな る地形勾配に沿うように，微地形に配慮して北西 - 南 東方向に配置された.

・それらは，縱断勾配が最も大きく，地形上顕著な谷筋 を通る本町通りを基軸として，表-5に示すような雨水 の排水勾配を確保するため，尾根筋（微高地）もしく は谷筋（微低地）に配慮しながら，およそ 30 間間隔 で配置された。

・城へ向かう街路と直交する街路は，まず，微低地の窪 地を貫くように下横町が配置された。

・さらに，下横町を基軸として北西へ，およそ 60 間ず つ隔てて中横町及び上横町が配置された.

・下横町の南東に並行する街路は, 塩町の南西側は下横 町を基軸としておよそ 60 間隔てて配置され，北東側 は地形及び接続する街路の影響から 60 間より狭い間 隔で配置された。

○宅地及び武家屋敷の割り付け

・地区中心部の宅地及び武家屋敷は，城へ向かう街路に 間口を向けて割り付けられ，町人地においては両側町 が形成された。

- 大明小路及び瑞相寺小路では，奥行 15 間の武家屋敷 が割り付けられた.
・材木町筋では，背割線を介して隣接する武家屋敷との 取り合いから，奥行が 15 間よりも短い 11〜13 間の宅 地が割り付けられた。

・本町通りでは，北東側は背割線を介して隣接する武家 屋敷との取り合いから，奥行が概ね 15 間の宅地が割 り付けられ，北西側は背割線を介して隣接する材木町 筋の宅地奥行との取り合いから奥行が 15 間よりも若 干長い宅地が割り付けられた。

・一部の宅地では，同一街区内で隣接する藩の主要施設 や武家屋敷，あるいは寺院の影響から，極端に奥行の 短い宅地も存在した。

○大坂及び江戸の設計論理との比較

岩国の錦見地区における城下町設計の論理と，大坂及 び江戸の町人地における城下町設計の論理を比較すると， 以下の類似点及び相違点を見出すことができる.

まず，町割の基軸については，雨水の排水勾配を確保 するため，方位に則ることよりも微地形一の配慮を優先 させて町人地のメインストリートを敷設し，それを基軸 として町割を行う点が共通している。，一方，大坂や江戸 では町人地に引込まれた水路も町割の基軸となっていた が，錦見地区では水路の引込みがないことから，街路の みが町割の基軸である点が相違している.

街区の設計基準については，大坂は 40 間四方正方形 街区，江戸は 60 間四方正方形街区であるのに対し，錦 見地区は 60 間 $\times 30$ 間の長方形街区が基準となっている. 
このように, 街区の基準は各城下町で相違しているが, 街区辺に間口を向けて宅地を割り付ける点は類似してい る.しかし，錦見地区の場合，街区短辺が 30 間と短く, そのため街区長辺に間口を向けて宅地を割り付けると, 宅地奥行が 30 間の半分，つまり 15 間となる.これは, 近世城下町のなかでは比較的短い宅地奥行であり（表4）, 錦見地区では狭い面積に必要数の宅地を割り付け ざるを得なかったことから，このように宅地奥行や街区 辺を短くしなければならなかったと考える. なお，こう した街区の配置にあたっては，微地形に配慮して街路網 を配置していることから，必然的に街区の基準を柔軟に 変化させながら配置しており，そのため基準とはずれた 不整形街区が多数発生している. この点は, 各城下町で 類似している.

宅地の割り付けについては, 街路を挟んだ両側の宅地 で一つの町を構成する両側町を形成している点は類似し ている。一方，宅地奥行は，大坂及び江戸においては 20 間が中心であったのに対して，錦見地区は 15 間が中 心であった．前述の通り，こうした錦見地区の比較的短 い宅地奥行は，狭い面積に必要数の宅地を割り付けざる を得なかったためであると考える．また，大坂及び江戸 では, 街路を挟んだ両側の宅地がほぼ等しい奥行となる よう割り付けられたのに対して，錦見地区では，同一街 区に背割線を介して隣接する藩の主要施設や武家屋敷の 影響から，必ずしも街路の両側で等しい奥行ではない宅 地が割り付けられている。 これらの相違点は, 岩国の立 地が城下町を開くには平地部の面積が不十分であったこ とから ${ }^{87}$, 錦見地区に武家地と町人地が混在せざるを得 ず，そのために生じた設計論理の特質であると考える.

\section{5. 方法論の考察}

本研究では，近世城下町の設計論理を読み解く方法論 について, 既往研究の方法論の適用上の課題を踏まえ, 宅地奥行及び街区辺の長さの分析にあたっては近世の絵 図や文献史料を用い，さらに微地形の分析にあたっては 下水道工事に際して作成された地形図を用いるなどの改 良を加え，近世城下町岩国の錦見地区における城下町設 計の論理の解明を試みた。

その結果, 前章までに示した通り, 改良した方法論に 基づき，錦見地区の設計論理を読み解くことができた. こうした研究成果は, 明治初期における大縮尺の近代測 量図が作成されていない城下町においても，その設計論 理を読み解く道を開くとともに，城下町間の設計論理の 比較に基づき，各城下町に共通する設計論理や，あるい は各城下町の設計論理の特質を見出寸可能性を示唆する 成果である.
一方，前述の通り，大坂や江戸においては，宅地奥行 及び街区辺の長さを記した近世の絵図や文献史料が一部 しか遺されていないため, 設計論理の解明には，明治初 期に作成された近代測量図を分析史料として用いざるを 得なかった，換言すれば，錦見地区のように，宅地奥行 及び街区辺の長さを記した近世の絵図や文献史料が遺さ れている場合には，そうした史料を用いて設計論理の分 析を行ったほうが，近代以降の街区や宅地の改変等に伴 う計測誤差が発生する可能性を排除することができるこ とから，より精密な分析を行うことができると考える. すなわち, この点において, 本研究を通して城下町の設 計論理を読み解く方法論を精緻化することができたと考 える.

\section{6. まとめ}

本研究では，既往研究において筆者らが提示した近世 城下町町人地の設計論理を解明するための方法論に基づ き，史料の残存状況に応じて方法論に改良を加えたうえ で，近世城下町岩国の錦見地区における設計論理の解明 を試みた. その結果, 表-1に示寸設計論理のうち, 絵図 及び地図の計測に基づき, 街区形態及び宅地奥行のモ ジュールを明らかにするとともに, 微地形の分析を踏ま えて町割の基軸を明らかにした。加えて, 文献史料及び 絵図の分析から, 設計単位及び開発過程を読久解いた.

これらの要点は, 以下のとおりである.

・城へ向かう北西 - 南東方向の街路は, 雨水の排水勾配 を確保するため, 縦断勾配が最も大きく, 地形上顕著 な谷筋を通る本町通りを基軸として，尾根筋（微高地） もしくは谷筋（微低地）に配慮しながら, 北西から南 東に向けて緩やかに低くなる地形勾配に沿うように 30 間間隔で配置された.

・城一向かう街路と直交する北東 - 南西方向の街路は, 微低地の窪地を貫く下横町を基軸として, およそ 60 間間隔で配置された。

・こうした微地形に配慮した街路配置の影響から，街区 についても微地形に応じて基準を柔軟に変化させなが ら配置された。

・町人地の宅地や武家地の武家屋敷の間口は，いずれも 城へ向から街路に向けられ，さらに町人地には両側町 が形成された。

・宅地及び武家屋敷の割り付けにあたっては, 武家屋敷 の奥行 15 間を優先的に確保し, 背割線を介してそれ らに隣接寸る町人地の宅地は, 武家屋敷の奥行との取 り合いで奥行が決められた.

・こうした町割及び屋敷割は，1600年代初頭に錦見の中 心部である地区西部で行われたが，その後錦川沿いや 
今津へと続く地区東部へ市街地が拡張される際には, 複雑な地形の影響から不整形街区が多数発生した.

・以上に示した錦見地区における町割の基軸設定や街区 配置の方法は，大坂及び江戸の町人地における設計論 理と概ね類似しているが，15 間という近世城下町と しては比較的短い宅地奥行や，背割線を介して隣接す る武家屋敷等の影響を強く受けた宅地の割り付け方法 は，大坂及び江戸とは相違しており，これは，立地の 制約から武家地と町人地が混在する錦見地区ならでは の設計論理の特質ということができる.

これらの研究成果は，近世城下町岩国の錦見地区にお ける城下町設計の論理に, より論理的で新たな解釈を加 える成果である.

また，錦見地区の分析を通して改良・精緻化した方法 論は，これまで困難であった近世城下町の設計論理の解 明に新たな道を開く研究成果である.

謝辞 : 本研究は, 岩国市からの委託研究「錦帯橋と近世 城下町の大規模橋梁との比較分析調査」及び JSPS 科研 費 JP25870782，JP16K06546 の助成を受けたものである. また, 岩国徵古館の松岡智訓氏をばめ, 調査にご協力 いただいた岩国市の方々に厚く御礼申し上げる.

\section{補注}

[1]『明治以前日本土木史』88)によると，江戸時代の街路面の 具体的な維持修繥方法に関して, 1648 (慶安元) 年 2 月, 幕府は江戸市街の道路築方并下方浚方について以下のよ うに令している.

一，町中海道惡敷所へ浅草砂に海砂まぜ，一町之内高ひ くなき様に，中高に築可申候，并ごみ又どろにて海 道つき申間敷事,

一，下水等表之みぞ滯なき様，所々にてごみをさら一上 げ可申候，下水へごみあくた少も入申間敷候，若ご みあくた入候は心゙可営曲事事,

さらに，1651（慶安 4）年 2 月 19 日には，幕府は以下の 町触を出している。

一, 町中道あしき所一浅草砂を敷, 中高に作り可申候, 勿論どろあくたにて築申まじき事,

一，表裏之下水，無滯水通り候様，町中申合，さらへ可 申候, 云々，

つまり, 街路面の維持修繥にあたっては, 粗粒の切込砂 利（「浅草砂」）に細粒の海砂を配合して，細粗均分の 切込砂利を街路の悪所に敷き，また街路の横断形状を蒲 針型に中高に仕上げ，排水に留意して街路面を固めてい たことがわかる。また，1657（明暦3）年正月に発生した 明暦の大火直後の 3 月に, 幕府は復興に関する「普請作 事の定」を数回にわたって示達している. その中で, 街 路の復興に関して, 町の両側で高低が生じないよう申し 合わせて地形を築き，また，街道筋においては前後続き 合わせの隣町との釣り合い良く築くといった，街路の横 断形状と緥断形状に関する要諦を指示している. このよ うに，江戸時代の街路面の維持修繥においては，路面の 凹凸の補修や街路の横断形状を中高に仕上げるために若
干の盛土は行われたと考えられるが，それらは，例えば 街区を挟んで並行に隣り合う街路など, 街路間の相対的 な標高差に対して大きく影響を与えるものではなかった と考えられる.さらに, 明暦の大火直後の「普請作事の 定」にあるように，街路の縦断方向の標高差にも配慮し た維持修繥が行われていたと考えられる，すなわち，町 割が継承されている場合においては，こうした街路間の 相対的な標高差や街路の縦断方向の標高差についても, 江戸期を通してほぼ変化がなかったと考える.さらに, 明治以降においても，下水道が整備されるまでは，雨水 等は地表面の高低差を利用して排水されることから, 町 割に大きな変化がない場合には，こうした相対的な標高 差も継承されていると考えるのが素直である.

\section{参考文献}

1) 伊藤毅：近世大坂成立史論, p. 27, 生活史研究所, 1987.

2) 玉井哲雄 : 都市史における都市空間研究, 日本都市 史入門 I 空間, pp. 133-134, 東京大学出版会, 1989.

3) 阿部貴弘, 篠原修: 近世城下町大坂, 江戸の町人地 における城下町設計の論理, 土木学会論文集 D2（土 木史），Vol. 68, No. 1, pp. 69-81, 2012.6.

4) 阿部貴弘, 篠原修 : 近世城下町大坂の上町地区にお ける城下町設計の論理, 土木学会論文集 D2（土木 史）, Vol. 68, No. 1, pp. 1-10, 2012.1.

5) 池田佳介, 阿部貴弘, 篠原修: 近世城下町大坂の下 船場地区における城下町設計の論理, 土木学会論文 集, No.758/IV-63, pp. 97-116, 2004.1.

6)池田佳介, 阿部貴弘, 篠原修 : 近世城下町大坂の船 場・島之内地区における城下町設計の論理，土木史 研究, 21 巻, pp. 13-24, 2001.6.

7) 阿部貴弘, 篠原修: 江戸における城下町中心部の都 市設計, 土木学会論文集, No.632/IV-45, pp. 63-76, 1999.10.

8) 竹林隆夫 : 都市構造から見た城下町一岩國城下町の 場合一, 社会科研究, pp. 87-93, 1956.

9)上杉和央：岩国の文化的景観一地理的条件に関する 調查一, 平成 27 年度岩国市文化的景観第 1 次調査報 告書（案），pp. 15-28，岩国市，2016.3.

10) 松岡智訓：岩国の町割, 究極の名橋錦帯橋, 錦帯橋 世界文化遺産専門委員会, pp. 16-19, 岩国市錦帯橋世 界遺産推進室, 2013.

11) 松岡智訓：岩国の町割, 究極の名橋錦帯橋, 錦帯橋 世界文化遺産専門委員会, p. 14, p. 19, 岩国市錦帯橋世 界遺産推進室, 2013.

12) 西村睦男: 藩領人口と城下町人口, 歴史地理学, 111 号, p. 6, 歴史地理学会, 1980.12 .

13) 阿部貴弘, 篠原修: 江戸における城下町中心部の都 市設計，土木学会論文集，No. 632/IV-45, pp. 63-76, 1999.10.

14）阿部貴弘，篠原修：近世城下町大坂の上町地区にお ける城下町設計の論理, 土木学会論文集 D2（土木 史），Vol. 68, No. 1, pp. 1-10, 2012.1.

15）池田佳介, 阿部貴弘, 篠原修: 近世城下町大坂の下 船場地区における城下町設計の論理, 土木学会論文 集, No.758/IV-63, pp. 97-116, 2004.1.

16）池田佳介, 阿部貴弘, 篠原修: 近世城下町大坂の船 場 - 島之内地区における城下町設計の論理, 土木史 研究, 21 巻, pp. 13-24, 2001.6. 
17) 阿部貴弘, 篠原修：近世城下町大坂，江戸の町人地 における城下町設計の論理, 土木学会論文集 D2（土 木史），Vol. 68, No. 1, pp. 69-81, 2012.6.

18）清水靖夫：二万分一迅速測図の内容について，歴史 地理学紀要第 21 巻, 地図と歴史地理, pp. 103-122, 歴 史地理学会, 1979.3 .

19) 岩国市教育委員会 : 岩国城下町岩国市岩国地区伝統 的建造物群保存対策調查報告書, p. 47, 岩国市教育委 員会，2005.3.

20) 岩国市教育委員会：岩国城下町 岩国市岩国地区伝統 的建造物群保存対策調査報告書, p. 29-31, 岩国市教育 委員会, 2005.3.

21) 岩国市教育委員会 : 岩国城下町岩国市岩国地区伝統 的建造物群保存対策調査報告書, pp. 38-39, 岩国市教 育委員会，2005.3.

22）松口輝久・吉田高子：大阪船場南部地区の町割と街 区構成について 近世大阪城下町の構成と形成過程に 関する研究 その 3 , 日本建築学会計画系論文集, 61 巻, 486 号, pp. 177-186, 1996.

23) 岩淵令治：江戸の沽券図について, 国立歴史民俗博 物館研究報告, 第 204 集, pp. 61-99, 2017.2.

24) 天満類子：岩国の文化的景観一建築物等に関寸る調 查, 平成 27 年度岩国市文化的景観第 1 次調査報告書 （案），pp. 34-35, 岩国市，2016.3.

25) 岩国市教育委員会：岩国城下町 岩国市岩国地区伝統 的建造物群保存対策調査報告書, pp. 38-39, 岩国市教 育委員会, 2005.3.

26) 岩国市教育委員会：岩国城下町岩国市岩国地区伝統 的建造物群保存対策調查報告書, pp. 48-49, 岩国市教 育委員会，2005.3.

27) 岩国市教育委員会 : 岩国城下町 岩国市岩国地区伝統 的建造物群保存対策調查報告書, pp. 32-33, 岩国市教 育委員会, 2005.3.

28）岩国市教育委員会：岩国城下町岩国市岩国地区伝統 的建造物群保存対策調查報告書, p. 8, p39, 岩国市教育 委員会, 2005.3.

29) 岩国市教育委員会 : 岩国城下町岩国市岩国地区伝統 的建造物群保存対策調查報告書, p. 8, p. 29, 岩国市教 育委員会, 2005.3.

30) 玉置豊次郎：日本都市成立史, p. 435, 理工学社, 1974.

31) 中西和子 : 織豊期城下町にみる町割プランの変容, 歴史地理学, Vol. 45, No. 2 (213), pp. 28-29, 歴史地理学 会, 2003.

32) 矢守一彦 : 城下町のかたち, p. 47, 筑摩書房, 1988.

33) 足利健亮 : 中近世都市の歴史地理, pp. 119-121, 地人 書房, 1984.

34) 玉置豊次郎：日本都市成立史, pp. 504-505, 理工学社, 1974.

35) 矢守一彦: 都市図の歴史, pp. 372-377, 講談社, 1974.

36) 矢守一彦: 都市プランの研究, pp. 54-55, 大明堂, 1970.

37) 玉置豊次郎：日本都市成立史, pp. 440-445, 理工学社, 1974.

38）宮本雅明：大坂城下町の形成，図集日本都市史，pp. 132-133, 東京大学出版会, 1993.

39) 中西和子 : 織豊期城下町にみる町割プランの変容, 歴史地理学, Vol. 45, No. 2 (213), pp. 29-31, 歴史地理学 会, 2003
40) 内田九州男 : 豊臣秀吉の大坂建設, よみがえる中世 2 本願寺から天下一へ大坂, pp. 49-51, 平凡社, 1989.

41) 33)玉置豊次郎：日本都市成立史, pp. 446-447, 理工学 社, 1974.

42) 矢守一彦 : 城下町のかたち, pp. 145-146, 筑摩書房, 1988.

43) 玉置豊次郎：日本都市成立史, pp. 447-448, 理工学社, 1974.

44) 宮本雅明: 織豊期の城下町, 図集日本都市史, p. 129, 東京大学出版会, 1993.

45) 矢守一彦 : 都市プランの研究, p. 310, p. 328, 大明堂, 1970.

46) 矢守一彦: 城下町のかたち, pp. 50-51, 筑摩書房, 1988.

47) 足利健亮 : 中近世都市の歴史地理, pp. 120-121, 地人 書房, 1984.

48) 玉置豊次郎：日本都市成立史, p. 449, 理工学社, 1974.

49) 宮本雅明: 畿内城下町の形成, 図集日本都市史, pp. 160-161, 東京大学出版会, 1993.

50) 宮本雅明：城下の町人地, 図集日本都市史, p. 176, 東京大学出版会, 1993.

51) 伊藤毅: 畿内城下の町亡町家, 図集日本都市史, pp. 246-247, 東京大学出版会, 1993.

52) 矢守一彦 : 都市プランの研究, pp. 268-269, 大明堂, 1970.

53) 矢守一彦 : 城下町のかたち, p. 51, pp. 158-162, 筑摩書 房, 1988 .

54) 玉置豊次郎：日本都市成立史, pp. 449-450, 理工学社, 1974.

55) 矢守一彦: 城下町のかたち, pp. 51-52, pp. 69-70, 筑摩 書房, 1988.

56) 玉置豊次郎：日本都市成立史, pp. 451-458, 理工学社, 1974.

57) 高橋康夫 : 織豊期の京都, 図集日本都市史, pp. 130131, 東京大学出版会, 1993.

58) 伊藤毅：近世京都の成立, 図集日本都市史, pp. 188189, 東京大学出版会, 1993.

59) 矢守一彦: 都市プランの研究, p. 308, 大明堂, 1970.

60) 矢守一彦: 都市図の歴史, pp. 220-223, 講談社, 1974.

61) 矢守一彦: 城下町のかたち, pp. 13-16, 筑摩書房, 1988.

62) 足利健亮 : 中近世都市の歴史地理, pp. 172-187, 地人 書房, 1984.

63) 玉置豊次郎：日本都市成立史, p. 461, 理工学社, 1974.

64) 土本俊和 : 城下町 - 伏見, 京の城下町化, 眓集日本 都市史, pp. 138-139, 東京大学出版会, 1993.

65) 中西和子：織豊期城下町にみる町割プランの変容, 歴史地理学, Vol. 45, No. 2 (213), pp. 31-33, 歴史地理学 会, 2003 .

66) 矢守一彦: 城下町のかたち, pp. 52-53, 筑摩書房, 1988.

67) 足利健亮 : 中近世都市の歴史地理, pp. 118-121, 地人 書房, 1984.

68）玉置豊次郎：日本都市成立史, pp. 463-464, 理工学社, 1974.

69) 矢守一彦：城下町のかたち, pp. 156-158, 筑摩書房, 1988. 
70) 玉置豊次郎：日本都市成立史，p. 502，理工学社， 1974.

71) 玉置豊次郎：日本都市成立史, pp. 510-512, 理工学社, 1974.

72) 宮本雅明：ヴィスタと景観演出，図集日本都市史，p. 174, 東京大学出版会, 1993.

73) 伊藤毅 : 江戸の町, 図集日本都市史, p. 225, 東京大 学出版会, 1993.

74) 矢守一彦: 都市プランの研究, pp. 314-317, 大明堂, 1970.

75) 矢守一彦: 城下町の地域構造, pp. 385-408, 名著出版, 1987.

76) 矢守一彦: 城下町のかたち, pp. 60-61, 筑摩書房, 1988.

77) 玉置豊次郎：日本都市成立史, pp. 512-514, 理工学社, 1974.

78) 宮本雅明: 城下町・名古屋, 図集日本都市史, pp. 166-167, 東京大学出版会, 1993.

79) 伊藤毅：江戸の町, 図集日本都市史, p. 225, 東京大 学出版会, 1993.

80) 矢守一彦 : 都市プランの研究, p. 314-317, 大明堂,
1970.

81) 矢守一彦: 都市図の歴史, pp. 383-388, 講談社, 1974.

82) 矢守一彦：城下町のかたち, p. 61, 筑摩書房, 1988.

83) 玉置豊次郎：日本都市成立史, pp. 467-468, 理工学社, 1974.

84) 中西和子 : 織豊期城下町にみる町割プランの変容, 歴史地理学, Vol. 45, No. 2 (213), pp. 36-38, 歴史地理学 会, 2003 .

85) 岩国市教育委員会 : 岩国城下町 岩国市岩国地区伝統 的建造物群保存対策調查報告書, p. 8, p. 29, 岩国市教 育委員会, 2005.3.

86) 阿部貴弘, 篠原修: 近世城下町大坂, 江戸の町人地 における城下町設計の論理, 土木学会論文集 D2（土 木史），Vol. 68, No. 1, pp. 69-81, 2012.6.

87) 松岡智訓：岩国の町割, 究極の名橋錦帯橋, 錦帯橋 世界文化遺産専門委員会, p. 14, 岩国市錦帯橋世界遺 産推進室, 2013.

88) 土木學會編 : 明治以前日本土木史, pp. 962-964, 岩波 書店, 1936.

(2019. 1. 24 受付)

\section{A STUDY ON THE DESIGN PRINCIPLES OF NISHIMI DISTRICT IN THE CASTLETOWN OF IWAKUNI}

\section{Takahiro ABE and Naomichi MATSUSHITA}

Castle towns in the modern era had unique urban fabric composed of well-developed infrastructures, such as streets, waterways, and drainage. These elements have long interested researchers in the fields of urban history, architectural history, and others. However, the principles of the design of the castle town have not been fully understood. Therefore, there has been a growing request to perform research on it in the field of history of civil engineering from the viewpoint of the infrastructure alignment of streets, waterways, drainage, and others.

The purpose of this study was to understand the design principles of Nishimi district in the castle town of Iwakuni. In this study, using the methodology, shown in the authors' previous research, of the quantitative analysis to understand the design principles by using modern surveying maps, the design principles of Nishimi district have been explained. Furthermore, the authors' methodology has been improved through the analysis in this study, and it has been clarified that the improved methodology would be useful to understand the design principles in the castle towns. 